\title{
Type and quantity of biochar influenced soil microbial activity and carbon priming effect
}

\author{
O tipo e a quantidade de biocarvão influenciaram a atividade \\ microbiana e o efeito priming do carbono no solo
}

\author{
José Ilmar Tínel de Carvalho Junior ${ }^{1}$; Maria Isidória Silva Gonzaga²*; André \\ Quintão de Almeida ${ }^{3}$ J Jady Araújo ${ }^{4}$; Lúcia Catherinne Oliveira Santos ${ }^{5}$
}

\begin{abstract}
Biochar has shown much potential to be used as soil amendment and conditioner as well as an effective alternative to waste disposal. However, the effect of biochar on soil organic matter varies according to the type of feedstock. This study aimed to evaluate the influence of different types and rates of application of biochar on soil microbial activity and on soil carbon priming effect. The incubation experiment was set up as a completely randomized design in a $2 \times 5$ factorial scheme, with two types of biochar (coconut husk and orange bagasse) and five rates of application $\left(0,5,10,15\right.$ and $\left.30 \mathrm{tha}^{-1}\right)$, with three replications. Soil microbial activity was evaluated through the concentration of $\mathrm{CO}_{2}$ released from the soil during a period of 130 days. Carbon priming effect was determined based on the $\mathrm{CO}_{2}$ respired in the biochar treated soil and in the control soil. Both biochars increased the total oxidizable carbon in the soil when they were applied at $30 \mathrm{tha}^{-1}$, however, the orange bagasse biochar was more effective than the coconut biochar. Coconut biochar increased the cumulative soil microbial respiration at all rates of application during the incubation period, therefore, it contributed to a positive carbon priming effect and should be applied with caution to avoid excessive loss of carbon from the soil. Orange bagasse biochar had little influence on the cumulative $\mathrm{CO}_{2}$ emission, except at $15 \mathrm{tha}^{-1}$, which increased soil microbial activity.
\end{abstract}

Key words: Black carbon. Waste management. Environmental sustainability.

\section{Resumo}

O biocarvão tem mostrado grande potencial para uso como insumo e condicionador de solo, assim como uma alternativa eficiente para a disposição de resíduos. Contudo, o efeito do biocarvão sobre a matéria orgânica do solo varia de acordo com o tipo de biomassa. O presente estudo objetivou avaliar a influência de diferentes tipos e doses de biocarvão na atividade microbiana e no efeito priming do carbono do solo. O experimento de incubação foi desenvolvido em desenho inteiramente casualizado, em esquema factorial $2 \times 5$, com dois tipos de biocarvão (casca de coco seco e bagaço de laranja) e cinco doses $\left(0,5,10,15\right.$ and $\left.30 \mathrm{t} \mathrm{ha}^{-1}\right)$, com três repetições. A atividade microbiana do solo foi

${ }^{1}$ Eng ${ }^{\circ}$ Florestal, M.e em Recursos Hídricos, Universidade Federal do Sergipe, UFS, São Cristóvão, SE, Brasil. E-mail: jrtinel@ gmail.com

${ }^{2}$ Eng $^{\mathrm{a}}$ Agr ${ }^{\mathrm{a}}$, Prof ${ }^{\mathrm{a}} \mathrm{Dr}^{\mathrm{a}}$, Departamento de Engenharia Agronômica, UFS, São Cristóvão, SE, Brasil. E-mail: mariaisisilva@gmail. com

3 Eng ${ }^{\circ}$ Florestal, Prof. Dr., Departamento de Engenharia Florestal, UFS, São Cristóvão, SE, Brasil. E-mail: andreqa@gmail.com

${ }^{4}$ Discente, Curso de Engenharia Agronômica, Departamento de Engenharia Agronômica, UFS, São Cristóvão, SE, Brasil. E-mail: jadyaraujo@outlook.com

5 Eng ${ }^{a}$ Florestal, M.e, UFS, São Cristóvão, SE, Brasil. E-mail: ktherinne_love@gmail.com

* Author for correspondence 
avaliada por meio da concentração de $\mathrm{CO}_{2}$ liberado durante 130 dias. $\mathrm{O}$ efeito priming do carbono foi determinado com base no $\mathrm{CO}_{2}$ respirado do solo tratado com biocarvão e do controle. Os dois biocarvões aumentaram a concentração de carbono total oxidável no solo quando aplicados na dose de $30 \mathrm{t} \mathrm{ha}^{-1}$; contudo, o biocarvão de bagaço de laranja foi mais eficiente do que o biocarvão de coco. O biocarvão de coco aumentou a concentração de carbono respirado acumulado em todas as taxas de aplicação durante o period de incubação, portanto, contribuiu para o efeito priming positivo e deve ser aplicado com cuidado para evitar perdas excessivas de carbono do solo. O biocarvão de laranja influenciou o carbono respirado acumulado apenas na dose de $15 \mathrm{t} \mathrm{ha}^{-1}$.

Palavras-chave: Carbono preto. Manejo de resíduos. Sustentabilidade ambiental.

\section{Introduction}

Soil carbon (C) plays a major role in the functioning of soils which support many ecosystems services. Highly weathered tropical soils rely mostly on soil organic matter (SOM) to supply plants nutrients, to regulate water supply and to maintain biological activity (FAGERIA, 2012). However, soil and climate conditions in the tropics stimulate decomposition and limit the buildup of SOM that is added to soil as crop residues, manures, agroindustry residues, biosolids and many others. In fact, low organic matter content and bad management practices in tropical soils have been a constraint for their agricultural use and have led to the degradation of many agroecosystems (GUIMARÃES et al., 2013; SABEN JUNIOR et al., 2014; GONZAGA et al., 2016).

The transformation of biomass residues and organic wastes into biochar to use as soil amendment and conditioner has been proposed as a method for the long-term storage of organic carbon, which at the same time will improve soil quality and reduce atmospheric emissions (PAZ-FERREIRO et al., 2014). The benefits of biochar in soil are related to its recalcitrant nature which allows a long lifetime in the environment. However, one of the major concerns with the use of biochar for agronomic purpose is its priming effect on the native SOM (SINGH; COWIE, 2014; ZHENG et al., 2018). By increasing the $\mathrm{pH}$ of acidic soils, biochar improves soil quality and microbial activity, therefore, causing a priming effect through the stimulation of the native SOM decomposition (SINGH; COWIE, 2014). However, a negative priming effect has also been reported (LU et al., 2014). According to the authors, the presence of toxic compounds in some biochars as well as the reduced availability of dissolved organic $\mathrm{C}$ in soil treated with biochar resulted in a decreased microbial activity and consequent decrease in SOM degradation.

Regardless of the biochar biomass precursor, only a small part of the carbon in biochar is labile and can be readily decomposed whereas the major part represents the core structure of a highly recalcitrant material (WANG et al., 2016). However, precise information about long-time biochar stability and the effect of biochar on the degradation of native SOM is still confusing. Laboratory experiments have indicated that only about $5 \%$ of the biochar is degraded within the period of the incubation study (ZIMMERMAN, 2010). Lanza et al. (2015) applied maize straw biochar to a soil at a rate of $0.5 \%$ in a10 day incubation study and observed that biochar addition had no impact on soil respiration. Paz-Ferreiro et al. (2015) investigated the microbial activity of a range of biochar types in a soil incubation experiment during 10 days and observed that soil respiration increased after biochar addition. The gathered information leads one to think that the effect of biochar on soil basal respiration is soil and biochar specific, and therefore needs more investigation.

In order to understand the extension of biochar degradation and its effect on soil organic matter, we set up a laboratory study to test the effect of two different biochars (coconut husk and orange 
bagasse) and different rates of application on soil microbial respiration and on the degradation of the native soil organic matter.

\section{Material and Methods}

The soil used in this experiment was taken from a fallow field at the Federal University of Sergipe experimental station, São Cristóvão, Sergipe. The soil was air-dried and sieved to pass through a $2 \mathrm{~mm}$ screen and presented the following characteristics: $71.6 \%$ sand, $13.4 \%$ silt, $15.0 \%$ clay, $\mathrm{pH}: 4.64$, EC:
$0.63 \mathrm{dS} \mathrm{m}^{-1}$, O.M.: $11.1 \mathrm{~g} \mathrm{~kg}^{-1}$, CEC: 1.88 cmolc kg1, P: $1.82 \mathrm{mg} \mathrm{kg}^{-1}, \mathrm{~K}: 25.4 \mathrm{mg} \mathrm{kg}^{-1}$, Al: 0.45 cmolc $\mathrm{kg}^{-1}$, Ca: 0.72 cmolc kg-1, Mg: 0.65 cmolc kg-1. The soil was classified as a Yellow Ultisol (SANTOS et al., 2013). Biochars were produced from coconut husks and orange bagasse, in a slow pyrolysis reactor, a Top-Lit Updraft retort unit, which is a micro-kiln that uses a reburner to eliminate volatile byproducts of pyrolization (NSAMBA et al., 2015), at approximately $500^{\circ} \mathrm{C}$. Biochar characteristics are presented in Table 1.

Table 1. Characteristics of the biochar from coconut husks and orange bagasse.

\begin{tabular}{lcc}
\hline Biochar characteristics & Coconut husks & Orange bagasse \\
\hline Ash $(\%)$ & 10.1 & 16.1 \\
Volatile matter (\%) & 15.0 & 17.3 \\
Fixed C (\%) & 75.0 & 66.5 \\
$\mathrm{C}(\%)$ & 79.8 & 72.1 \\
$\mathrm{~N}(\%)$ & 0.42 & 2.55 \\
$\mathrm{H}(\%)$ & 2.21 & 1.83 \\
$\mathrm{O}(\%)$ & 7.42 & 7.29 \\
$\mathrm{C} / \mathrm{N}$ & 190 & 28.3 \\
$\mathrm{O} / \mathrm{C}$ & 0.09 & 0.10 \\
$\mathrm{H} / \mathrm{C}$ & 0.03 & 0.02 \\
$(\mathrm{O}+\mathrm{N}) / \mathrm{C}$ & 0.10 & 0.14 \\
$\mathrm{FC} /(\mathrm{FC}+\mathrm{VM})$ & 0.83 & 0.80 \\
$\mathrm{pH}$ & 10.0 & 9.73 \\
EC $\left(\mathrm{dS} \mathrm{m}^{-1}, 2{ }^{\circ} \mathrm{C}\right)$ & 0.43 & 0.33 \\
Porosity $(\AA)$ & 77.2 & 99.1 \\
Specific surface $\left(\mathrm{m}^{2} \mathrm{~g}^{-1}\right)$ & 39.1 & 67.5 \\
\hline
\end{tabular}

$\mathrm{FC}=$ fixed carbon; $\mathrm{VM}=$ volatile matter.

The experiment was conducted as a completely randomized design in a 2 x 5 factorial scheme, with two types of biochar (coconut husk and orange bagasse) and 5 rates of application $(0,5,10,15$ and $30 \mathrm{t} \mathrm{ha}^{-1}$ ), with three replications. Each dose of biochar was incorporated with a $25 \mathrm{~g}$ air-dried soil in a $100-\mathrm{mL}$ plastic container, and homogeneously mixed. Deionized water was added to reach $80 \%$ field capacity. Periodically during the incubation, deionized water was cautiously sprayed to bring samples back to $80 \%$ field capacity.

Amended soil was then placed in a $1.2-\mathrm{L}$ airtight measuring-jar (wide mouthed glass canning jar) with a $50 \mathrm{~mL}$ vial containing $20 \mathrm{~mL} \mathrm{NaOH}$ solution $0.1 \mathrm{~mol} \mathrm{~L}^{-1}$ to trap respired $\mathrm{CO}_{2}$. A control (a measuring-jar containing soil but no biochar) 
was used to assess the basal soil respiration. A blank (measuring-jars containing no soil, but the $\mathrm{NaOH}$ vial) was made to account for carbonatation of $\mathrm{NaOH}$ when opening the jars and replacing the $\mathrm{NaOH}$ vials before the next measurement period. The treatments were incubated at $25{ }^{\circ} \mathrm{C}$ for 130 days. Since the rates of $\mathrm{CO}_{2}-\mathrm{C}$ released from soils amended with organic residues are generally high during the first days of incubation, respired $\mathrm{CO}_{2}$ trapped in alkali solutions was measured daily for the first two weeks. As the measurements were becoming relatively low, the frequency of evaluation was reduced to every three days and then weekly. The determination of the respired $\mathrm{CO}_{2}$ on alkali trap solutions was performed directly through $0.1 \mathrm{~mol}$ $\mathrm{L}^{-1} \mathrm{HCl}$ titration of $\mathrm{NaOH}$ after addition of $5 \mathrm{~mL}$ $0.05 \mathrm{~mol} \mathrm{~L}^{-1} \mathrm{BaCl}_{2}$, which reacts with $\mathrm{CO}_{2}$ to form $\mathrm{BaCO}_{3}$ precipitated, and 3 drops of phenolphthalein indicator, which changes the color of the solution from pink to colorless to indicate the final point of the reaction (ALEF; NANNIPIERI,1995).

Total organic carbon content, $\mathrm{pH}$ and electrical conductivity of the treatments (soil and biochar mixture) were determined in samples taken from a parallel incubation trial consisting of the same treatments as the respiration study. Total organic carbon was determined by the Walkley Black method (NELSON; SOMMERS, 1982). Electrical conductivity and soil $\mathrm{pH}$ were determined according to Gaskin et al. (2008).

All results were expressed as an average of three replicates. Treatments effects were determined by analysis of variance using $\mathrm{R}$ software version 1.12.2. ( $\mathrm{R}$ DEVELOPMENT CORE TEAM, 2013). Considering that biochar rates of application are quantitative factors, we have perform5ged regression analysis $(\mathrm{P}<0.05)$. All the figures were created using SigmaPlot software. The Tukey mean separation test was applied to treatment means at $P<$ 0.05 probability level to compare different biochars at the same rate of application.

\section{Results and Discussion}

\section{Biochar characteristics}

The chemical and physical characteristics of the biochars are presented in Table 1. Due to the nature of the two feedstocks (crop residues), their biochars presented many similar properties such as the ratios $\mathrm{O} / \mathrm{C}, \mathrm{H} / \mathrm{C}$ and $(\mathrm{O}+\mathrm{N}) / \mathrm{C}$, varying from $0.02-0.14$, which are often used to predict the degree of aromaticity, recalcitrance and stability of the biochar. When these ratios are high (close to 0.6 , which represent the uncharred feedstock), the biochar is usually designated as soil amendment whereas lower ratios indicate a good fit of biochar as soil conditioner due to its high recalcitrance and stability (CELY et al., 2015). According to the O/C and $\mathrm{H} / \mathrm{C}$ ratios, both biochars were well pyrolyzed and have the potential to remain in soil for a long period of time.

Biochar from orange bagasse (OBB) presented more ash, volatile matter and $\mathrm{C} / \mathrm{N}$ ratio, and lower fixed carbon than the coconut shell biochar (CSB), indicating greater susceptibility to degradation as compared to the CSB. The higher volatile matter content of the $\mathrm{OBB}$ is probably related to its porosity and specific surface area, characteristics that are very important for the agronomic use of biochar. These properties of the OBB have shown that this biochar has great potential as a sorbent for the clean up of contaminated soil and water (TRAN et al., 2016). Another important property of biochar is the presence of different organic functional groups which allow for the interactions of biochar with the soil constituents. Even though the two biochars have many similar properties, the FTIR spectra in Figure 1 shows that they present many differences regarding the type of functional groups in their structure. The orange bagasse biochar presented a greater variety of functional groups including those that are related to its cellulosic $\left(700-1.600 \mathrm{~cm}^{-}\right.$ $\left.{ }^{1}\right)$ and volatile matter content ( - $\mathrm{NO}_{2}$ groups with $1.377 \mathrm{~cm}^{-1}$ ), which could influence soil microbial activity. More specifically, functional groups such 
as $\mathrm{OH}\left(3.866\right.$ e $\left.3.226 \mathrm{~cm}^{-1}\right), \mathrm{C}-\mathrm{H}\left(2.319 \mathrm{~cm}^{-1}\right), \quad \mathrm{OBB}$, whereas $\mathrm{OH}\left(3.800 \mathrm{~cm}^{-1}\right), \mathrm{N}=\mathrm{C}=\mathrm{O}(2.300$ $\mathrm{C}=\mathrm{O}\left(1.775 \mathrm{~cm}^{-1}\right), \mathrm{N}-\mathrm{H}\left(1.570 \mathrm{~cm}^{-1}\right), \mathrm{C}-\mathrm{O}\left(1.377 \mathrm{~cm}^{-1}\right), \mathrm{C}=\mathrm{C}\left(1.553 \mathrm{~cm}^{-1}\right)$ and $\mathrm{C}-\mathrm{H}\left(817 \mathrm{~cm}^{-1}\right)$ were $\left.\mathrm{cm}^{-1}\right)$ and $\mathrm{S}=\mathrm{O}\left(1.026 \mathrm{~cm}^{-1}\right)$ were present in the identified in the CSB.

Figure 1. Fourier-transform infrared (FT-IR) spectra of the biochars obtained from orange bagasse and coconut husks at temperature of approximately $600{ }^{\circ} \mathrm{C}$ using a slow pyrolysis reactor.
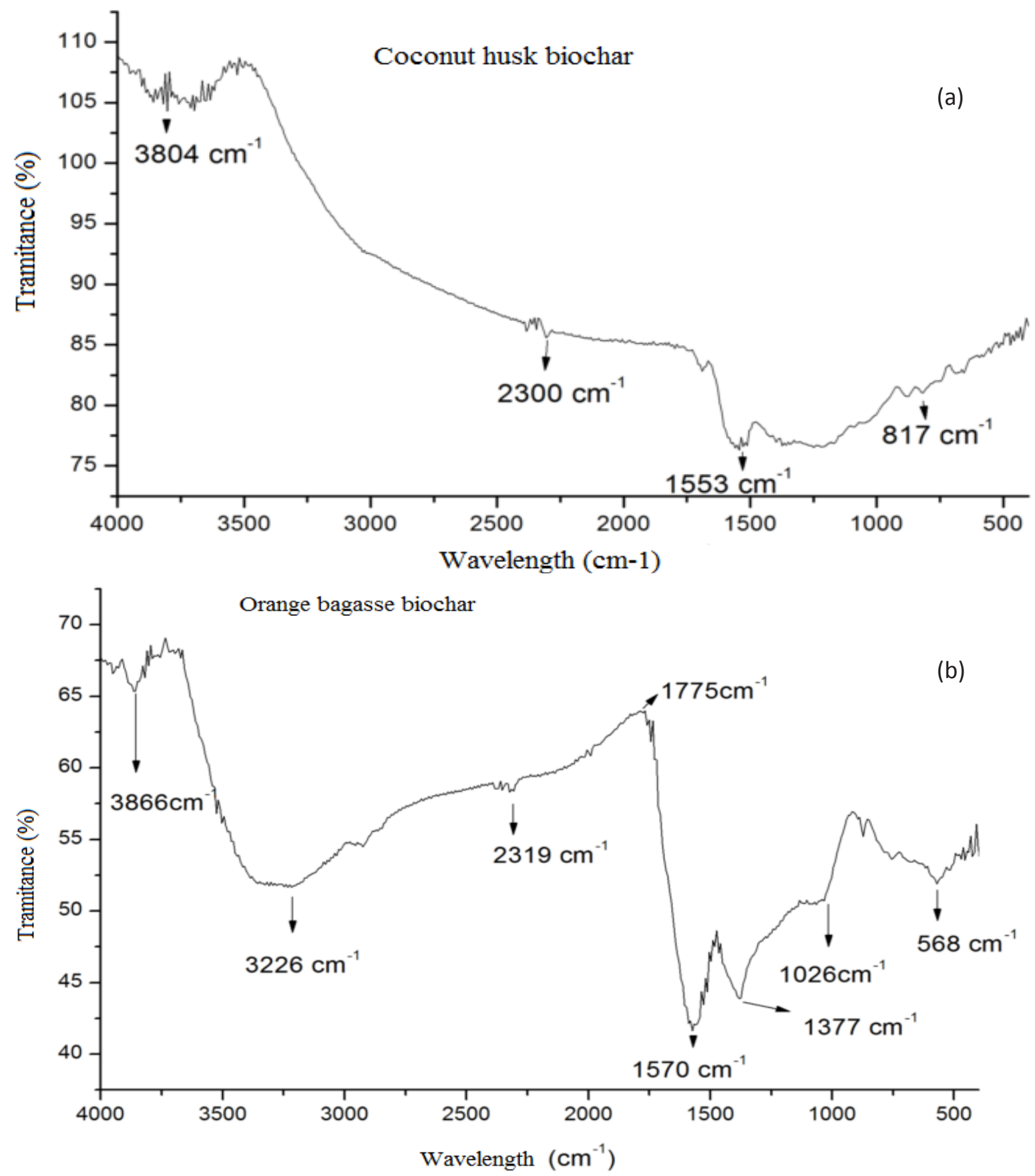
Effect of biochar on the total oxidizable carbon and on soil microbial activity

The effect of biochar on the total oxidizable carbon (TOC), operationally defined by Calvelo Pereira et al. (2011) as the labile fraction of soil C that can be easily degraded by soil microbes, varied significantly $(\mathrm{P}<0.05)$ according to the type of biomass and rate of application (Table 2). The CSB significantly increased (33\%) the TOC fraction only when it was applied at the highest rate $\left(30 \mathrm{t} \mathrm{ha}^{-1}\right)$, suggesting that the CSB is composed mostly of a higly persistent form of organic carbon and will not contribute much to the labile $\mathrm{C}$ in soil, instead, this will play an important role on the biochar residence time in the soil (SINGH; COWIE, 2014). Application of 15 and 30 t ha $^{-1}$ of the OBB significantly increased the TOC content by $65 \%$ and $93 \%$, respectively, which will likely contribute to an increase in the soil microbial activity as the labile fraction is expected to be easily degraded by soil microbes. The results of our study has some resemblance with the findings of Yousaf et al. (2017) who evaluated the effect of a wood-based biochar on the soil oxidizabe carbon. The authors observed a three-fold increase in the TOC after 120 days of incubation, a high increase considering the characteristics and lignin content of wood biochars.

Table 2. Total oxidizable carbon (TOC), cumulative $\mathrm{CO}_{2}$ evolved $\left(\mathrm{C}-\mathrm{CO}_{2}\right)$, percent of the TOC that was lost by microbial respiration $\left(\mathrm{C}-\mathrm{CO}_{2} / \mathrm{TOC}\right)$, and percent of the native TOC that was microbial respired $\left(\mathrm{C}-\mathrm{CO}_{2} / \mathrm{Native}\right.$ TOC) of the coconut shell biochar (CSB) and orange bagasse biochar (OB7B) after a 120 days mineralization study. Means followed by the same lower case letter in a row are not significantly different $(\mathrm{P}<0.05)$.

\begin{tabular}{|c|c|c|c|c|c|c|c|c|}
\hline \multirow{3}{*}{$\begin{array}{l}\text { Rate of } \\
\text { application } \\
\left(\mathrm{t} \mathrm{ha}^{-1}\right)\end{array}$} & \multicolumn{8}{|c|}{ Biochar type } \\
\hline & CSB & OBB & CSB & OBB & CSB & OBB & $\mathrm{CSB}$ & OBB \\
\hline & $\operatorname{COT}(\%)$ & & \multicolumn{2}{|c|}{$\mathrm{C}-\mathrm{CO}_{2}\left(\mathrm{mg} \mathrm{g}^{-1}\right.$ soil $)$} & \multicolumn{2}{|c|}{$\mathrm{C}-\mathrm{CO}_{2} / \mathrm{COT}(\%)$} & \multicolumn{2}{|c|}{$\mathrm{C}-\mathrm{CO}_{2} /$ Native $\mathrm{COT}(\%)$} \\
\hline 0 & $0.69 a$ & $0.69 \mathrm{a}$ & $0.55 \mathrm{a}$ & $0.55 \mathrm{a}$ & $8.09 \mathrm{a}$ & $8.09 a$ & $8.06 \mathrm{a}$ & $8.06 \mathrm{a}$ \\
\hline 5 & $0.80 \mathrm{a}$ & $0.63 \mathrm{a}$ & $0.73 \mathrm{a}$ & $0.49 \mathrm{~b}$ & $9.17 \mathrm{a}$ & $5.62 b$ & $10.68 \mathrm{a}$ & $7.15 b$ \\
\hline 10 & $0.83 a$ & $0.87 \mathrm{a}$ & $0.64 \mathrm{a}$ & $0.48 b$ & $7.84 \mathrm{a}$ & $7.57 \mathrm{a}$ & $9.29 \mathrm{a}$ & $6.97 \mathrm{~b}$ \\
\hline 15 & $0.84 b$ & $1.14 \mathrm{a}$ & $0.46 \mathrm{~b}$ & $0.52 \mathrm{a}$ & $5.62 \mathrm{a}$ & $4.75 \mathrm{a}$ & $6.68 b$ & $7.68 \mathrm{a}$ \\
\hline 30 & $1.01 \mathrm{~b}$ & $1.33 \mathrm{a}$ & $0.55 \mathrm{a}$ & $0.50 \mathrm{a}$ & $5.52 \mathrm{a}$ & $3.77 \mathrm{~b}$ & $8.02 \mathrm{a}$ & $7.33 b$ \\
\hline
\end{tabular}

The soil microbial activity evaluated through the determination of the respired $\mathrm{CO}_{2}$ during a period of 130 days was differently affected by the different types and rates of application of the biochars (Figure 2). During the first days of incubation, it was observed an increase in the microbial activity in the biochar treatments as compared to the control, however, as time went by, there was a clear diference on the respired $\mathrm{CO}_{2}$ between the two biochars. After 30 days of evaluation, the CSB (Figure 2A), especially at low rates of application, kept stimulating the evolution of $\mathrm{CO}_{2}$ almost throughout the incubation period, which can be also observed through the cumulative $\mathrm{CO}_{2}$ (Figure 3A). Conversely, the periodic evaluation showed that the OBB (Figure
2B) had a discrete effect on $\mathrm{CO}_{2}$ evolution. The cumulative $\mathrm{CO}_{2}$ released from the OBB treatment (Figure 3B) was greater than the control only when the biochar was applied at a rateof $15 \mathrm{tha}^{-1}$, resulting in positive priming effect. According to the data presented in Table 2, it is interesting to note that, even though the OBB presented lower fixed $\mathrm{C}$ as well as total $\mathrm{C}$ (Table 1), the higher oxidizable $\mathrm{C}$ content of the OBB treatments was expected to contribute more to the release of $\mathrm{CO}_{2}$ due to microbial respiration. Additonally, the lower $\mathrm{C} / \mathrm{N}$ ratio as well as the higher volatile matter content of the $\mathrm{OBB}$, which is inversely proportional to the amount of fixed carbon (Table 1), could potentially increase the evolution of $\mathrm{CO}_{2}$ from the incubated soil. 
Figure 2. Carbon dioxide emission rate during 120 day incubation after addition of (A) Coconut husk biochar and (B) orange bagasse biochar to a Yellow Ultisol. All data are mean values and the bars represent standard deviations of the means $(\mathrm{n}=3)$.
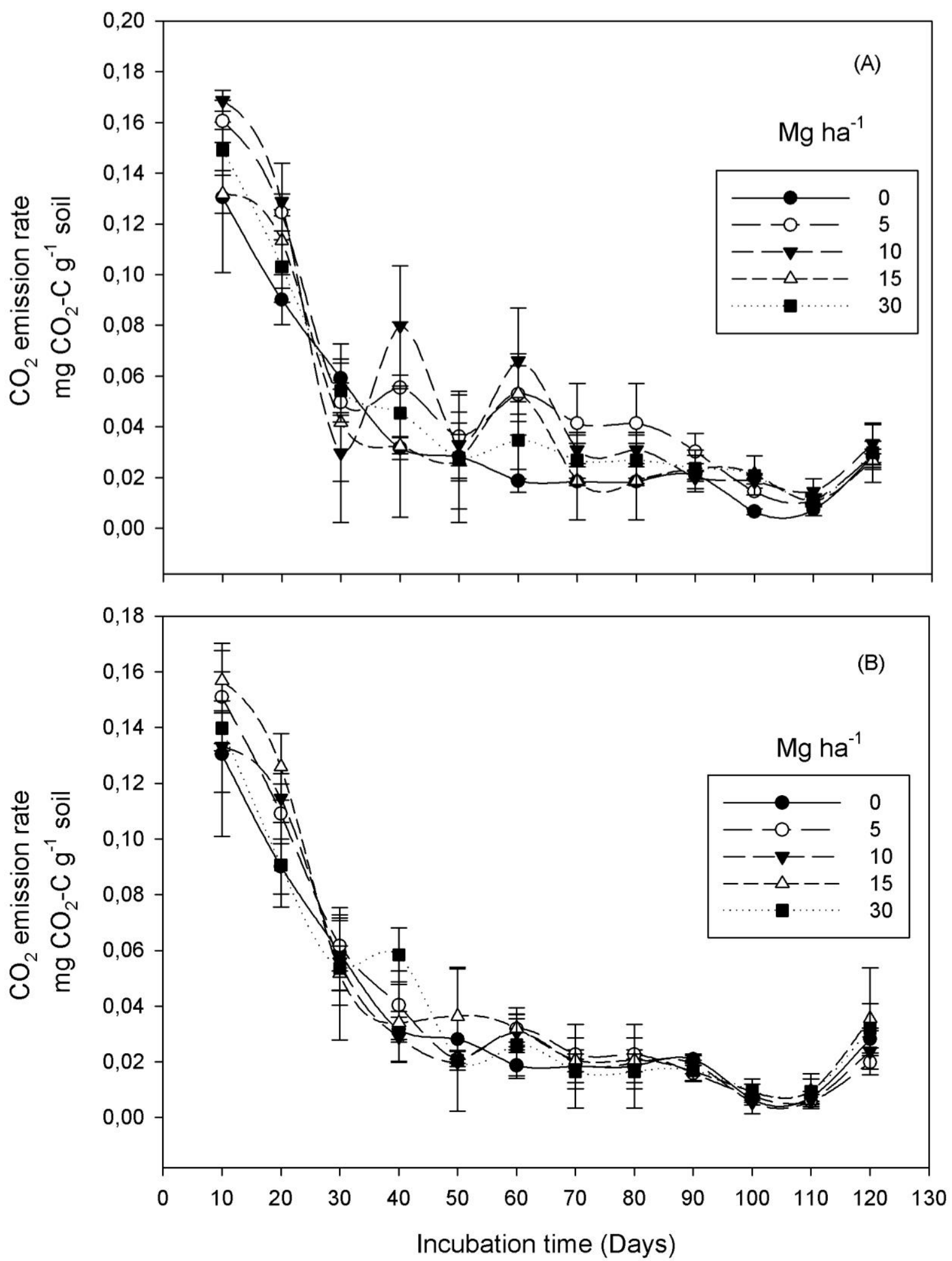
Figure 3. Cumulative $\mathrm{CO}_{2}$ evolved during 120 day incubation after addition of (A) Coconut husk biochar and (B) orange bagasse biochar to a Yellow Ultisol. All data are mean values of 3 replicates.
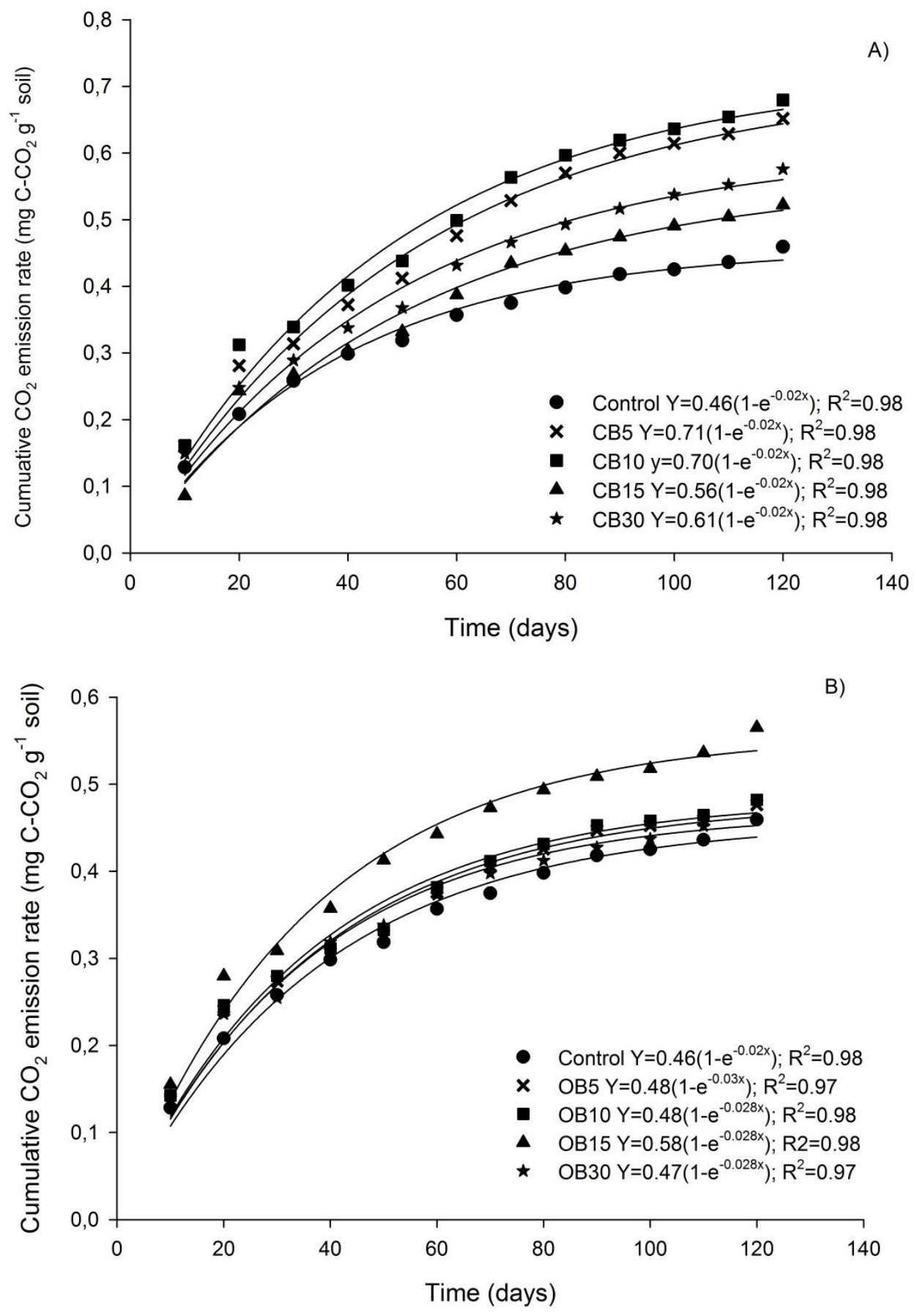

Application of CSB significantly $(\mathrm{P}<0.05)$ increased $(23 \%)$ the respired $\mathrm{CO}_{2}$ whereas $\mathrm{OBB}$ reduced (13\%) (Table 2), confirming that biochars from different feedstocks present variable stability and residence time in soil. However, based on the volatile matter content and $\mathrm{C} / \mathrm{N}$ ratio of the $\mathrm{OBB}$, it was expected an increase in the respired $\mathrm{CO}_{2}$ when compared with the CSB. The quality of the volatile matter likely played a role on this outcome. Some studies have shown that the presence of 
toxic substances in biochars is related to the volatile matter, causing toxicity to soil microbes and reducing soil organic matter decomposition (BUDAI et al., 2016; ZIMMERMAN et al., 2011). Another important point to be considered here is the higher porosity and specific surface area of the OBB (Table 1), which could probably have contributed to the water retention in soil and consequent reduction in mincrobial activity. Similar results were observed by Hernandez-Soriano et al.(2016).

The percent of $\mathrm{C}$ that was released from the soil based on the total $\mathrm{C}$ (including biochar $\mathrm{C}$ ) and on the native soil $\mathrm{C}$ (excluding biochar $\mathrm{C}$ ) was determined in order to evaluate the influence of biochar on the mineralization of the native soil organic matter. The proportion of the TOC that was respired based on the total oxidizable $\mathrm{C}$ varied from $5.52-9.17 \%(\mathrm{CSB})$ and from 3.77 - $7.57 \%$ (OBB). Considering that $8.09 \%$ of $\mathrm{C}$ was respired in the control soil, addition of biochar did not increase the amount of $\mathrm{CO}_{2}$ that was released from the soil, indicating a small fraction of the labile $\mathrm{C}$ in the pyrolyzed residues. However, it was observed that both biochars influenced the release of $\mathrm{C}$ from the native soil organic matter, showing positive priming effects. Additionally, the effect of biochar was dependent on the rate of application. Application of $5 \mathrm{t} \mathrm{ha}^{-1}$ and $10 \mathrm{t} \mathrm{ha}^{-1}$ of CSB significantly increased microbial activity by $33 \%$ and $15 \%$, respectively, indicating an acceleration on the decomposition of soil organic matter and therefore a positive priming effect (LU et al., 2014). The increase in chemical hydrolysis caused by the increase in soil $\mathrm{pH}$ when biochar is applied to soil will likely improve microbial population, causing a positive priming effect in soil (YU et al., 2013). On the contrary, a negative priming effect was observed for the OBB at these same rates of application (5 $\left.-10 \mathrm{tha}^{-1}\right)$, with significant reduction (12\%) of the respired $\mathrm{CO}_{2}$ from the native soil organic matter. Biochar has also been reported to cause negative priming effect due to increase in the adsorption of dissolved organic $\mathrm{C}$, which reduces $\mathrm{C}$ availability to microbes, and due to toxic effects of biochar components (ZIMMERMAN et al., 2011).

The differences observed among these two biochars regarding their impact on the native soil organic matter suggest that specific properties of each pyrolyzed residue dictate their effect in soil, and for that matter, more investigation is needed. For instance, Jenkins et al. (2017) applied biochar derived from maize feedstocks to different soils in Europe and observed that biochar altered soil microbiome by modifying microbial communities. No research has been done on the effect of coconut husk and orange bagasse biochar on soil microbial ecology, which could shed some light on the C dynamics in soil.

\section{Conclusions}

Although both biochars come from plant residues and present some similar characteristics, specific properties caused significant differences in the carbon dynamics in soil. Both biochars increased the oxidizabel carbon content of the soil, however, particular characteristics of each biochar diffenrently influenced microbial activity and $\mathrm{CO}_{2}$ evolution. Coconut husk biochar resulted in positive priming effect at all rates of application, especially at lower doses, which suggests that, at a small amount, coconut biochar improves the soil environment for microbial growth and increases $\mathrm{CO}_{2}$ emissions to the atmosphere. At higher rates of application, coconut biochar can increase water retention and reduce microbial activity. Orange bagasse biochar did not influence microbial acitivity, except at 15 $\mathrm{t} \mathrm{ha}^{-1}$ application rate, which caused a positive priming effect and increased the loss of carbon from the soil.Therefore, the best rate of application seems to be related to the type of biochar. According to this study, higher rates of application of coconut biochar are more suitable for soil carbon dynamic. Conversely, orange bagasse biochar can be applied at a broader spectrum without causing adverse carbon emission. 


\section{Acknowledgments}

This research was funded by the Brazilian National Research Council (CNPq).

\section{References}

ALEF, K.; NANNIPIERI, P. Methods in applied soil microbiology and biochemistry. London: Academic Press, 1995. $576 \mathrm{p}$.

BUDAI, A.; RASSE, D. P.; LAGOMARSINO, A.; LERCH, T. Z.; PARUCH, L. Biochar persistence, priming and microbial response to pyrolysis temperature series. Biology and Fertility of Soils, Berlin, v. 52, n. 6, p. 749-761, 2016. DOI: 10.1007/s00374-016-1116-6

CALVELO PEREIRA, R.; KAAL, J.; CAMPSARBESTAIN, M.; PARDO LORENZO, R. AITKKENHEAD, W.; HEDLEY, M.; MACIAS, F.; HINDMARSH, J.; MACIÁ-AGULLÓ, J. A. Contribution to characterization of biochar to estimate the labile fraction of carbon. Organic Geochemistry, v. 42, n. 11, p. 1331-1342. DOI:10.1016/j.orggeochem.2011.09.002.

CELY, P.; GASCO, G.; PAZ-FERREIRO, J.; MENDEZ, A. Agronomic properties of bio-chars from different manure wastes. Journal of Analytical and Applied Pyrolysis, Amsterdam, v. 111, n. 1, p. 173-182, 2015. DOI: 10.1016/j.jaap.2014.11.014

FAGERIA, N.K. Role of soil organic matter in maintaining sustainability of cropping systems. Communications in Soil Science and Plant Analysis, New York, v. 43, n. 16, p. 2063-2113, 2012. DOI: 10.1080/00103624.2012.697234

GASKIN, J.; STEINER, C.; HARRIS, K.; DAS, K.; BIBENS, B. Effect of low-temperature pyrolysis conditions on biochar for agricultural use. Transactions of the ASABE, Saint Joseph, v. 51, n. 6, p. 2061-2069, 2008. DOI: $10.13031 / 2013.25409$

GONZAGA, M. I. S.; BISPO, M. V. C.; SILVA, T. L.; SANTOS, W. M.; SANTANA, I. L. Atlantic forest soil as reference in the soil quality evaluation of coconut orchards (Cocos nucífera L) under different management. Semina: Ciências Agrárias, Londrina, v. 37, n. 6, p. 3847 3858, 2016. DOI:10.5433/1679-0359.2016v37n6p3847

GUIMARÃES, D. V.; GONZAGA, M. I. S.; SILVA, T. O.; SILVA, T. L.; DIAS, N. S.; SILVA, M. I.; MATIAS, M. I. Soil organic matter pools and carbon fractions in soil under different land uses. Soil and Tillage Research, Netherlands, v. 126, n. 1, p. 177-182, 2013. DOI:10.1016/j.still.2012.07.010
HERNANDEZ-SORIANO， M. C.; KERRÉ, B.; KOPITTA, P. M.; HOREMANS, B.; SMOLDERS, E. Biochar affects carbon composition and stability in soil: A combined spectroscopy-microscopy study. Scientific Reports, v. 6, n. 25127, 2016. DOI: 10.1038/srep25127

JENKINS， J. R.; VIGER， M.; ARNOLD，Z. M.; HARRIS, M. V. Biochar alters the soil microbiome and soil function: results of next-generation amplicon sequencing across Europe. GCB Bioenergy, Hoboken, v. 9, n. 3, p. 591-612, 2017. DOI:10.1111/gcbb.12371

LANZA, G.; WIRTH, S.; GESSLER, A.; KERN, J. Short-term response of soil respiration to addition of chars: impact of fermentation post-processing and mineral nitrogen. Pedosphere, Beijing, v. 25, n. 5, p. 761769, 2015. DOI: 10.1016/S1002-0160(15)30057-6

LU, W.; DING, W.; ZHANG, J.; LI, Y.; LUO, J.; BOLAN, N.; XIE, Z. Biochar suppressed the decomposition of organic carbon in a cultivated sandy loam soil: a negative priming effect. Soil Biology and Biochemistry, Firenze, v. 76 , n. 1, p. 12-21, 2014. DOI:10.1016/j. soilbio.2014.04.029

NELSON, D. W.; SOMMERS, L. E. Total carbon, organic carbon and organic matter. In: PAGE, A. L.; MILLER, R. H.; KEENEY, D. R. (Ed.). Methods of soil analysis: chemical and microbiological properties. Part 2. Madison: Soil Science Society of America, 1982. p. 539-579.

NSAMBA, H.; HALE, S.; CORNELISSEN, G.; BACHMANN, R. Designing and Performance Evaluation of Biochar Production in a Top-Lit Updraft Up-scaled Gasifier. Journal of Sustainable Bioenergy Systems, Wuhan, v. 5, n. 2, p. 41-55, 2015. DOI: 0.4236/ jsbs.2015.52004

PAZ-FERREIRO, J.; FU, S.; MENDEZ, A.; GASCO, G. Interactive effects of biochar and the earhworm Pontoscolex corethrurus on plant productivity and soil enzymes activities. Journal of Soils and Sediment, New York, v.14, n.3, p. 483-494, 2014. DOI:10.1007/s11368013-0806-Z

PAZ-FERREIRO, J.; LIANG, C.; FU, S.; MENDEZ, A.; GASCO, G. The effect of biochar and its interaction with the earthworm pontoscolex corethrurus on soil microbial community structure in tropical soils. PLoS One, San Francisco, v. 10, n. 4, p. 1-11, 2015. DOI:10.1590/S010006832014000400021

SANTOS, R. D. dos; LEMOS, R. C. de; SANTOS, H. G. dos; KER, J. C.; ANJOS, L. H. C. dos; SHIMIZU, S. H. Manual de descrição e coleta de solo no campo. 6. ed. Viçosa: Sociedade Brasileira de Ciência do Solo, 2013. $100 \mathrm{p}$. 
SINGH, B. P.; COWIE, A. L. Long-term influence of biochar on native organic carbon mineralisation in a low-carbon clayey soil. Scientific Report, London, v.4, n.3687, p.1-9, 2014. DOI: 10.1038/srep03687

TEAM, R. C. R. A language and environment for statistical computing $R$ Foundation for statistical computing. Vienna, Áustria, 2013.

TRAN, H.; YOU, S. J.; CHAO, H. Effect of pyrolysis temperatures and times on the adsorption of cadmium onto orange peel derived biochar. Waste Management and Research, Thousand Oaks, v. 34, n. 2, p. 129-138, 2016. DOI: $10.1177 / 0734242 X 15615698$

WANG, J.; XIONG, Z.; KUZYAKOV, Y. Biochar stability in soil: meta-analysis of decomposition and priming effects. GCB Bioenergy, Hoboken, v. 8, n. 3, p. 512-523, 2016. DOI: $10.1111 / \mathrm{gcbb} .12266$

YOUSAF, B.; LIU, G.; WANG, R.; ABBAS, Q.; IMTIAZ, M.; LIU, R. Investigating the biochar effects on Cmineralization and sequestration of carbon in soil compared with conventional amendments using the stable isotope (delta C-13) approach. Global Change Biology Bioenergy, v. 9, n. 1, p. 1085-1099, 2017. DOI: 10.1111/gcbb.12401
YU, L.; TANG, J.; ZHANG, R.; WU, Q.; GONG, M. Effects of biochar application on soil methane emission at different soil moisture levels. Biology and Fertility of Soils, Berlin, v. 49, n. 2, p. 119-128, 2013. DOI: 10.1007/ s00374-012-0703-4

ZHENG, H.; WANG, X.; LUO, X.; WANG, Z.; XING, B. Biochar-induced negative carbon mineralization priming effects in a coastal wetland soil: roles of soil aggregation and microbial modulation. Science of the Total Environment, Amsterdam, v. 610-611, n. 1, p. 951960, 2018. DOI: 10.1016/j.scitotenv.2017.08.166

ZIMMERMAN, A. R. Abiotic and microbial oxidation of laboratory-produced black carbon (biochar). Environmental Science and Technology, Washington,v. 44 , n. 4, p. 1295-1301, 2010. DOI: 10.1021/es903140c

ZIMMERMAN, A. R.; GAO, B.; AHN, M-Y. Positive and negative carbon mineralization priming effects among a variety of biochar-amended soils. Soil Biology and Biochemistry, Firenze, v. 43, n. 6, p. 1169-1179, 2011. DOI: $10.1016 /$ j.soilbio.2011.02.005 
